\title{
Szójafajták gyökérnövekedésének és szárazságtürésének in situ vizsgálata elektromos kapacitás mérésével
}

\author{
CSERESNYÉS Imre*, RAJKAI Kálmán, TAKÁCS Tünde \\ Magyar Tudományos Akadémia, Agrártudományi Kutatóközpont, Talajtani és \\ Agrokémiai Intézet,
}

\section{Bevezetés}

A hagyományos gyökérvizsgáló módszerek destruktív jellegük miatt alkalmatlanok egyazon növény ismételt, in situ vizsgálatára. A növényt nem károsító eljárások (pl. minirizotron, MRI, izotópos nyomjelzés, röntgen) felhasználhatósága is gyakran korlátozott. Egyes módszerek csak a gyökérzet egy részéről szolgáltatnak információt, mások felbontóképessége pedig a hajszálgyökerek szintjén nem megfelelö, így a teljes gyökérrendszer tömegének és aktív felszínének meghatározására nem használhatóak (CAO et al., 2010).

A gyökér-talaj rendszer elektromos kapacitásának (EC) mérését elsőként CHLOUPEK (1972) alkalmazta. Kimutatta, hogy a termöközegbe helyezett talajelektród és a gyökérnyakba szúrt növényelektród között mérhető EC nagysága egyenesen arányos a gyökérzet felületével. A módszer előnye, hogy a mért EC a gyökér méretén túl annak aktivitásától is függ, így a gyökérzet aktuális müködési állapotát tükrözi. A rendszerben mérhető kapacitás megjelenését az aktív gyökérmembránok elektromos polarizációja és relaxációja idézi elő, mely az alkalmazott váltakozó áram amplitúdójában és fázisában egyaránt változást okoz. A módszer biofizikai alapjait elsőként DALTON (1995) ismertette elvi modelljében. E megközelítés a talajoldattal kontaktusban lévő, abszorptív gyökérrégiókat velük azonos átmérőjü, veszteséges hengerkondenzátorok párhuzamosan kapcsolt rendszereként értelmezi. A gyökér-talaj-elektród hálózatban a xylem- és phloemnedv belső, míg a talajoldat (tápoldat) külső vezetőként funkcionál, melyeket elektromosan szigetelö gyökérmembránok választanak el egymástól. A váltakozó áram hatására polarizálódó membrán, a kondenzátor dielektrikumaként, a gyökértalaj kontaktfelülettel arányos mennyiségü elektromos töltést tárol, kialakítva az EC-t. A fizikai kondenzátorok kapacitása függ a kitöltő dielektrikum relatív permittivitásától $\left(\varepsilon_{r}\right)$, a fegyverzetek felületétől $(A)$ és azok távolságától $(d)$. A gyökérben, mint hengerkondenzátorban $d$ értékét az adott gyökérszegmens átméröje határozza meg. A Dalton-modell kiegészítéseként RAJKAI és mtsai. (2005) egy kettős dielektrikumú kondenzátor-modell alkalmazását javasolták, figyelembe véve a talajoldat kapacitását is.

Az EC-mérés hátránya, hogy a talaj tulajdonságai (vízállapot, ionösszetétel, textúra) és a növényelektród helyzete jelentősen befolyásolják a mért elektromos jellemzőket (DALTON, 1995; OZIER-LAFONTAINE \& BAJAZET, 2005). A mérési adatok így csak azonos növényfaj, azonos közeg és azonos nedvességtartalom esetén hasonlíthatók össze (CHLOUPEK et al., 2010). E feltételek biztosítása mellett viszont az eljárással jól becsülhető a gyökérzet mérete mind laboratóriumi (PITRE et

Postai cím: CSERESNYÉS IMRE, Magyar Tudományos Akadémia, Agrártudományi Kutatóközpont, Talajtani és Agrokémiai Intézet, 1022 Budapest, Herman Ottó út 15.

*E-mail: cseresnyes.imre@ agrar.mta.hu 
al., 2010; CSERESNYÉS et al., 2013, 2014), mind szabadföldi körülmények között (PRESTON et al., 2004; SVAČINA et al., 2014).

A gyökérkapacitás mérését eredményesen alkalmazták nagyobb gyökértömeget fejlesztő árpa és búza genotípusok kiválogatása és keresztezése során (SvAČINA et al., 2014; HEŘMANSKÁ et al., 2015), valamint búzafajták vízhasznosító képességének meghatározásához (STŘEDA et al., 2012). Számos kultúrnövény (köztük szója) esetén mutattak ki fajtaspecifikus különbségeket a gyökérzet morfológiájában, növekedési ütemében, valamint víz- és tápanyagfelvételi aktivitásában (TURMAN et al., 1995; KUMAGAI \& SAMESHIMA, 2014). A vizsgálatokat a gyökérzet rendszeres destruktív mintavételezésével vagy videokamerákkal felszerelt minirizotron-rendszerrel végezték, különbözö termesztési körülmények között.

Munkánk célja volt annak igazolása, hogy az EC mérése - tenyészedénykísérletek során - alkalmas a gyökérnövekedési dinamika fajtaspecifikus különbségeinek monitorozására, valamint a biomassza-produkció becslésére. Vizsgáltuk, hogy a környezeti tényezők kedvezötlen változása (esetünkben szárazságstressz) milyen mértékben csökkenti az egyes fajták biomasszáját, és hogy e változás hogyan tükröződik a mért EC-ben. Tanulmányunkkal e gyors és egyszerü módszer fajtakísérletekben (pl. hibridszelekció, stressztürés-vizsgálatok) való hasznosságát igyekeztünk alátámasztani.

\section{Anyag és módszer}

A tenyészedény-kísérletet szója [Glycine $\max$ (L.) Merr.], több éréscsoportba tartozó nyolc fajtájával végeztük (1. táblázat).

\section{1. táblázat}

A vizsgált szójafajták jellemzői.

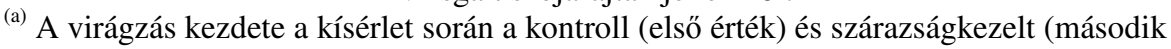
érték) növényeknél.

\begin{tabular}{cccc}
\hline (1) Fajta neve & (2) Fajta jelzés & (3) Éréscsoport & (4) Virágzás (nap) \\
\hline Bagera & BA & 00 & $40 / 35$ \\
Mentor & ME & 00 & $40 / 35$ \\
Aliz & AL & 0 & $55 / 47$ \\
Johanna & JO & 0 & $45 / 37$ \\
Martina & MA & 0 & $46 / 39$ \\
Emese & EM & I & $56 / 47$ \\
Sponsor & SP & I & $52 / 45$ \\
Zelma & ZE & I & $45 / 39$ \\
\hline
\end{tabular}

A magokat nedves vattapapírral bélelt petricsészékben 2 napig, $24{ }^{\circ} \mathrm{C}$-on, sötétben elöcsíráztattuk, majd - fajtánként 40 ismétlésben - egyesével 3,75 1-es tenyészedényekbe ültettük át. Közegként 3,3 kg, 0,7-1,1 mm szemcseméretü, 6,53 
pH-jú pumicitet (perlit) használtunk. A szabadföldi vízkapacitást és a hervadáspontot nyomásmembrános készülékkel 0,211 és $0,136 \mathrm{~cm}^{3} / \mathrm{cm}^{3}$ víztartalom értékeknek határoztuk meg.

A növényeket random elhelyezéssel, fényszobában 60 napig neveltük, $26 / 18{ }^{\circ} \mathrm{C}$ és 16/8 óra nappali/éjszakai hőmérséklet és megvilágítás, valamint 40-70\% relatív páratartalom mellett. A növények felének (kontroll) optimális vízellátást biztosítottunk (1. alább), a másik felét erős szárazságstressznek tettük ki. A kontroll csoportok közegét - tömegmérés mellett - naponta, csapvízzel szabadföldi vízkapacitásig öntöztük, tápanyag-ellátásukat pedig hetente $2 \times 150 \mathrm{ml}$ Hoaglandoldattal biztosítottuk. A stresszelt növények esetén a vízellátást négy, 10 napos periódus alatt $(9-18,23-32,36-45$ és 49-58. nap) jelentősen korlátoztuk: a periódusok kezdetétỏl a közeg víztartalmának hervadáspontra csökkenéséig (a növények korától függően 3-6 napig) az öntözést megszüntettük, majd a periódus végéig napi vízpótlással kevéssel a hervadáspont feletti értéken tartottuk. A növénytáplálást - a kontrollokéval megegyező napokon - hetente $2 \times 30 \mathrm{ml}$ ötszörös töménységủ Hoagland-oldattal végeztïk. Az egyes fajták virágzásának kezdetét (az egyedek 50\%-ának virágzása) feljegyeztük.

A gyökérkapacitást GW 8101G típusú LCR-mérőhíddal (GW Instek Co., Ltd., Taiwan) mértük $1000 \mathrm{~Hz}$ frekvencián, $1 \mathrm{~V}$ kapocsfeszültséggel, párhuzamos eredő kapacitásként $\left(\mathrm{C}_{\mathrm{p}}\right)$. A mérőfrekvenciát szakirodalmi adatok, valamint saját kísérleti eredményeink alapján választottuk meg (OZIER-LAFONTAINE \& BAJAZET, 2005; CSERESNYÉS et al., 2013). Talajelektródként a közegbe szúrt, $6 \mathrm{~mm}$ átmérőjü és 18 $\mathrm{cm}$ hosszú rozsdamentes acélrudat, növényelektródként a szárra $(15 \mathrm{~mm}$ magasságban) rögzített, $4 \mathrm{~mm}$ széles, rugós csipeszt alkalmaztunk. A megfelelő elektromos kontaktust a csipesz alá kent áramvezető gél biztosította (RAJKAI et al., 2005). A mérést a pumicit szabadföldi vízkapacitásra történő öntözését követően végeztuik; a nedvességtartalmat Trime FM3 TDR müszerrel is ellenőriztük.

A kontroll növények EC-jét a 7. és 60. nap között 16 alkalommal mértük a gyökérnövekedési dinamika pontosabb monitorozása érdekében. Mivel az ECértékek csak azonos nedvességtartalom mellett hasonlíthatók össze, a szárazságstressznek kitett növények EC-jét a 7. nap után csak a szárazságperiódusokat követő időszakokban, a kontrollokéval megegyező (20, 34, 48. és 60.) napokon határoztuk meg. Az utolsó EC-mérést követően a hajtásokat levágtuk, és a gyökérzetet a közegből folyóvízzel, szürő felett óvatosan kimostuk. A leveleket leválasztottuk, a növényenkénti levélfelületet szkenneléssel és képelemzéssel meghatároztuk. A leveleket a szárral egyesítettük, a hajtásokat és a gyökereket $70^{\circ} \mathrm{C}-o n$ súlyállandóságig szárítottuk. Száraztömegüket (továbbiakban: gyökér- és hajtástömeg) lemértük, majd kiszámítottuk a gyökér/hajtás arányt.

Az eredmények statisztikai elemzését Statistica programmal (ver. 12, Statsoft Inc., OK, USA) végeztük. Az EC- és biomassza-adatok összehasonlításához kétmintás $t$-próbát, illetve varianciaanalízist és Tukey-Kramer post-hoc tesztet alkalmaztunk. A csoportok szórásainak szignifikáns különbsége esetén ( $F$ - vagy Bartlett-próba alapján) az értékelést Welch-teszttel, illetve Kruskal-Wallis próbával és Dunn post-hoc teszttel végeztük. Szignifikáns különbséget $p<0,05$ esetén fogadtunk el. $\mathrm{Az}$ EC és a gyökértömeg közötti korrelációt lineáris 
regresszióanalízissel vizsgáltuk. A kapott regressziós egyenesek tengelymetszetét és meredekségét kovariancia-analízissel hasonlítottuk össze.

\section{Eredmények}

Az ismételt EC-mérések jól szemléltették a különböző szójafajták gyökérnövekedési dinamikájának különbségeit. A kontroll növények EC-je a vegetatív fázis során - fajtától és kortól függő intenzitással - folyamatosan emelkedett, majd ezt követően közel állandó értéket mutatott (1/A ábra). A Bagera, Johanna és Martina esetén egy lassúbb korai fejlődést követő hirtelen aktivitásnövekedést figyeltünk meg a 30. és 42. nap között, míg a többi fajta a vegetatív fázisban sokkal egyenletesebb gyökérnövekedést mutatott. Általánosan jellemző volt, hogy az EC növekedése hozzávetőleg a virágzás kezdetéig tartott, mely fajtától függően a 40. (Bagera és Mentor) és 56. nap (Emese) közti időszakra esett (1. táblázat). A korai virágzású Bagera és Zelma EC-je kis mértékben $(<2 \%)$ csökkent az utolsó két mérés (termésképzési fázis) során. A kísérlet végén a legnagyobb EC-t $(3,05 \mathrm{nF})$ a Martina mutatta, 30,9\%-kal meghaladva a legkisebb értéket $(2,33 \mathrm{nF})$ mutató Zelmát. A vizsgált szójafajták az utolsó napon mért gyökérkapacitásuk alapján négy, statisztikailag szignifikánsan elkülönülő csoportot alkottak.

A szárazságstressz gyökérnövekedést gátló hatása az EC értékekben is tükröződött. Az EC a 2. szárazságperiódus alatt még viszonylag intenzíven - bár a kontroll növényekénél lényegesen kisebb mértékben - emelkedett, majd a 3. periódus során az EC növekedése számottevően mérséklödött, különösen a Bagera, Johanna és Martina fajtáknál (1/B ábra).

A 60. napon mért EC értékek között szignifikáns különbségeket mutattunk ki. A legnagyobb kapacitást $(1,87 \mathrm{nF})$ az Emesénél mértük, mely 26,9\%-kal volt nagyobb a Bageráénál $(1,37 \mathrm{nF})$. A szárazságstressz hatására a virágzás 5-9 nappal korábban, a 35-47. nap között kezdődött (1. táblázat). A szárazságstressz egyes fajtákra gyakorolt hatását a fajták relatív EC értékével (a stresszelt növényeknél mért EC százalékos aránya a kontrollokéhoz viszonyítva) jellemeztük. A szárazperiódusok során a relatív EC folyamatosan csökkent, különösen a 2. és 3. periódusban a Bagera, Johanna és Martina esetén (2. ábra). A relatív EC alapján a legnagyobb szárazságtürést az Emese $(72,8 \%)$ és a Zelma $(71,2 \%)$ mutatta; mérsékelten szárazságtürő volt az Aliz, Sponsor és Mentor (64,6-66,9\%), míg a leginkább szárazságérzékenynek a Bagera, Johanna és Martina bizonyult (49,5$57,1 \%)$. 

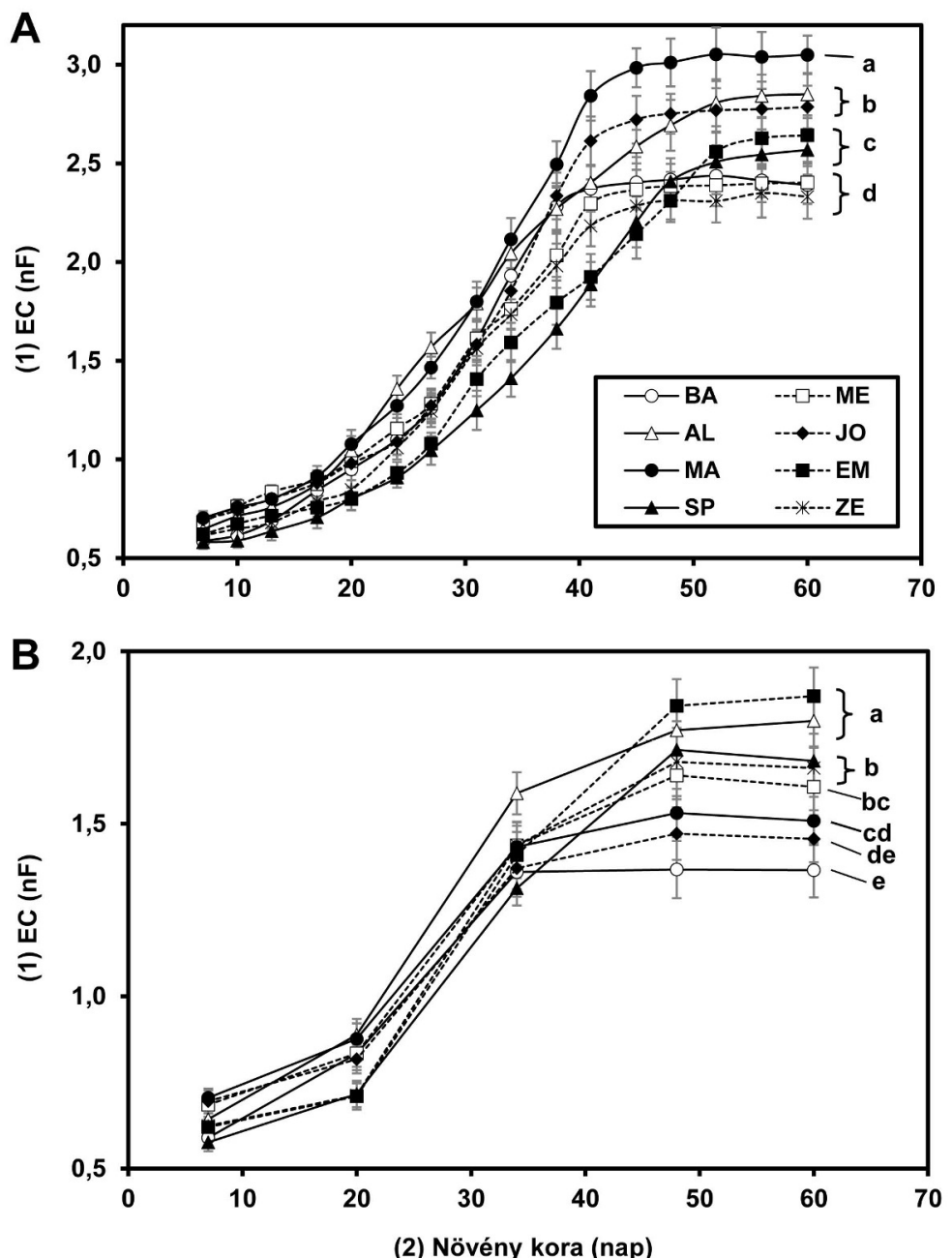

(2) Növény kora (nap)

\section{1. ábra}

A gyökér elektromos kapacitásának (EC) átlaga és szórása (A) a kontroll és (B) a szárazságkezelt szójafajták esetén. A kisbetük a Tukey-Kramer teszttel kapott, szignifikánsan $(p<0,05)$ különböző csoportokat jelzik. A fajták nevét lásd az 1. táblázatban. 


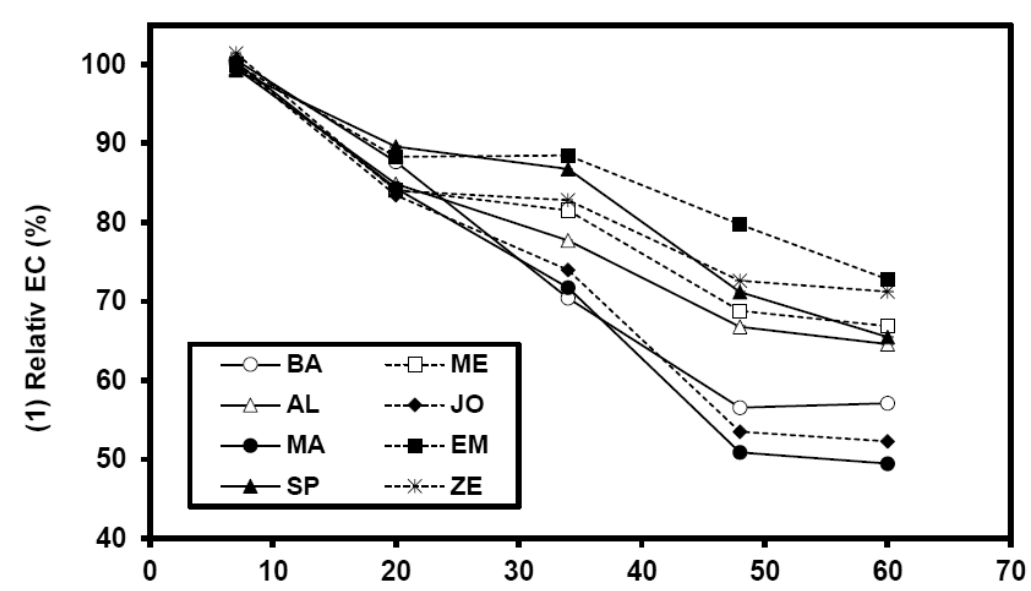

(2) Növény kora (nap)

\section{2. ábra}

A relatív elektromos kapacitás (EC; a szárazságkezelt növények elektromos kapacitásának aránya a kontroll növényekéhez viszonyítva) változása a vizsgált szójafajták esetén.

A fajták szignifikánsan eltérő biomassza-produkcióját a destruktív vizsgálat is alátámasztotta (csak a legfontosabb különbségeket mutatjuk be). A kontroll növények közül a legnagyobb gyökértömeget az Aliz, Martina és Johanna esetén találtuk (5,48 g, 5,48 g és 5,29 g; nem szignifikáns), míg a legkisebb gyökértömeggel a Bagera és Zelma (4,10 g és 4,18 g; nem szignifikáns) rendelkezett (3/A ábra). A Martina hajtástömege (17,78 g) ellenben szignifikánsan nagyobb volt mind az Alizénál (16,48 g), mind a Johannáénál (16,04 g; 3/B ábra). A legkisebb hajtástömeget a Zelma és Bagera produkálta (12,78 g és 13,24 g; nem szignifikáns). A vizsgált fajták a Bagera és Martina kivételével statisztikailag azonos $(0,322-0,332)$ gyökér/hajtás arányt mutattak (3/C ábra). A nagyobb hajtástömegnek köszönhetően a Martina gyökér/hajtás aránya $(0,304)$ szignifikánsan alacsonyabb volt, mint az Alizé és a Johannáe. A Bagera gyökér/hajtás aránya $(0,307)$ szignifikánsan eltért az Aliz, Johanna és Zelma értékeitől. A legnagyobb levélfelületet $\left(1973 \mathrm{~cm}^{2}\right)$ a Martina esetén mértük, ez szignifikánsan nagyobb volt, mint az Alizé $\left(1809 \mathrm{~cm}^{2}\right)$ és a Johannáe $\left(1805 \mathrm{~cm}^{2}\right.$; 3/D ábra). A legkisebb levélfelületet a Zelma, Mentor és Bagera mutatta $\left(1401 \mathrm{~cm}^{2}\right.$, $1413 \mathrm{~cm}^{2}$ és $1497 \mathrm{~cm}^{2}$; nem szignifikáns). 

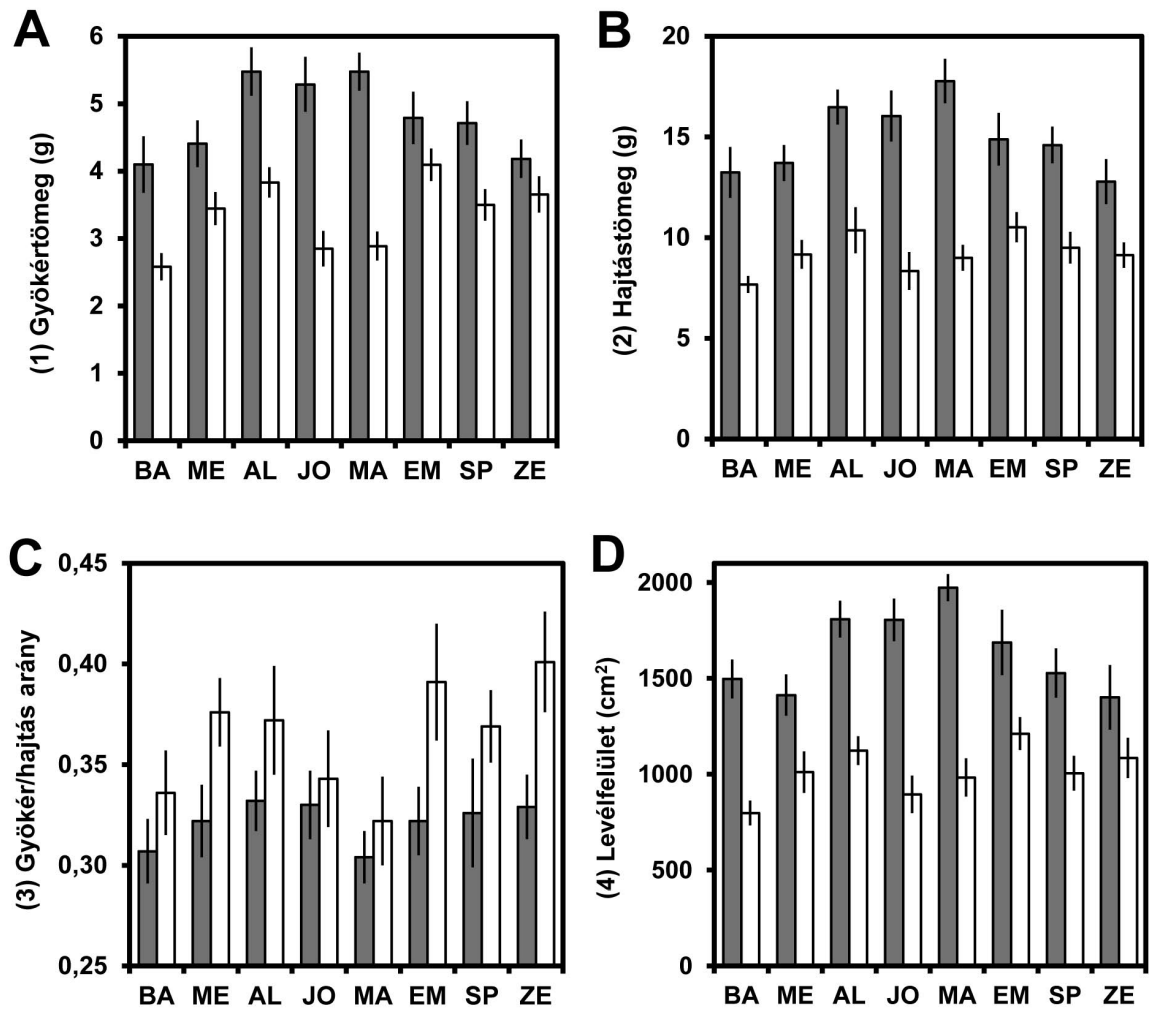

3. ábra

(A) A gyökér- és (B) hajtástömeg, (C) gyökér/hajtás arány és (D) levélfelület átlaga és szórása a kontroll és szárazságkezelt (szürke, illetve fehér oszlopok) szójafajták esetén. A fajták nevét lásd az 1. táblázatban.

Szárazságstressz mellett a legnagyobb gyökértömeget (4,09 g) az Emese produkálta, 58,6\%-kal meghaladva a legkisebb Bagera gyökértömegét (2,58 g; 3/A ábra). A vízhiány a gyökértömeget szignifikánsan csökkentette, 12,6\% (Zelma) és 47,3\% (Martina) közötti mértékben (2. táblázat).

A gyökértömeghez hasonlóan, a legnagyobb, illetve legkisebb hajtástömeget szintén az Emesénél (10,52 g), illetve a Bageránál (7,67 g) találtuk (3/B ábra). A szárazságstressz - fajtától függetlenül - nagyobb arányú csökkenést okozott a hajtás tömegében, mint a gyökérében, a változás 25,5\% (Zelma) és 49,1\% (Martina) között volt. A vízhiány hatására számottevő eltérések alakultak ki a gyökér/hajtás arányok között (3/C ábra). A legnagyobb gyökér/hajtás arányt a leginkább szárazságtürő Emesénél és Zelmánál találtuk $(0,391$ és 0,401), a mérsékelten toleráns Aliz, Mentor és Sponsor közepes $(0,369-0,376)$, az érzékeny Bagera, Johanna és Martina alacsony $(0,322-0,343)$ arányt mutatott. A szárazság változatos mértékben - minden fajtánál növelte a gyökér/hajtás arányt. Míg az arány az Emesénél és Zelmánál 21,4\%-kal, illetve 21,9\%-kal nőtt, addig a Mentor, 
Aliz és Sponsor 12,0-16,8\% közötti, a Bagera, Johanna és Martina mindössze 3,99,4\%-os változást mutatott (a Johannánál nem szignifikáns). A levélfelület $798 \mathrm{~cm}^{2}$ (Bagera) és $1212 \mathrm{~cm}^{2}$ (Emese) között alakult (3/D ábra), ami a kontrollhoz viszonyítva 23,6\% (Zelma) és 51,4\% (Martina) közötti csökkenést jelent.

\section{2. táblázat}

A szárazságkezelés hatása a szójafajták mért jellemzőire (százalékban kifejezett változás), kétmintás $t$-próbával kapott szignifikancia szintekkel. ***, **, * $p<0,001,0,01,0,05$; NS, nem szignifikáns. ${ }^{(a)}$ A fajták nevét lásd az 1. táblázatban.

\begin{tabular}{|c|c|c|c|c|c|}
\hline $\begin{array}{c}\text { (1) } \\
\text { Fajta } \\
\text { jelzés }{ }^{(a)}\end{array}$ & $\begin{array}{c}(2) \\
\text { Elektromos } \\
\text { kapacitás } \\
\end{array}$ & $\begin{array}{c}\text { (3) } \\
\text { Gyökértömeg }\end{array}$ & $\begin{array}{c}\text { (4) } \\
\text { Hajtástömeg }\end{array}$ & $\begin{array}{c}\text { (5) } \\
\begin{array}{c}\text { Gyökér/hajtás } \\
\text { arány }\end{array} \\
\end{array}$ & $\begin{array}{c}\text { (6) } \\
\text { Levélfelület }\end{array}$ \\
\hline BA & $-42.9 * * *$ & $-37.0 * * *$ & $-42.0 * * *$ & $+9.4 * *$ & $-46.7 * * *$ \\
\hline ME & $-33.1 * * *$ & $-21.8 * * *$ & $-35.1 * * *$ & $+16.8 * * *$ & $-28.5 * * *$ \\
\hline $\mathrm{AL}$ & $-36,9 * * *$ & $-30.0 * * *$ & $-34.6 * * *$ & $+12.0 * *$ & $-37.9 * * *$ \\
\hline JO & $-47.7 * * *$ & $-46.1 * * *$ & $-48.0 * * *$ & $+3.9^{\mathrm{NS}}$ & $-50.4 * * *$ \\
\hline MA & $-50.5 * * *$ & $-47.3 * * *$ & $-49.1 * * *$ & $+5.9 *$ & $-51.4 * * *$ \\
\hline EM & $-29.2 * * *$ & $-14.5 * * *$ & $-31.4 * * *$ & $+21.4 * * *$ & $-28.1 * * *$ \\
\hline SP & $-34.5 * * *$ & $-25.8 * * *$ & $-36.5 * * *$ & $+13.2 * * *$ & $-34.2 * * *$ \\
\hline $\mathrm{ZE}$ & $-28.8 * * *$ & $-12.6 * * *$ & $-25.5 * * *$ & $+21.9 * * *$ & $-23.6 * * *$ \\
\hline
\end{tabular}

A regresszióanalízis szoros lineáris korrelációt mutatott mind a kontroll $\left(\mathrm{R}^{2}=0,844 ; p<0,01\right)$, mind a stressznek kitett $\left(\mathrm{R}^{2}=0,936 ; p<0,01\right)$ növények EC-je és gyökértömege között, az egyenesek 0,437 és $0,317 \mathrm{nF} / \mathrm{g}$ gyökér meredekségeivel, valamint 0,528 és $0,546 \mathrm{nF} y$-tengely metszeteivel (4. ábra). Az ábrán látható, hogy a kontroll Martina és Bagera a gyökértömegükhöz viszonyítva nagyobb EC-t mutattak a többi fajtához képest. A kovariancia-analízis a stresszelt növények adataira illesztett egyenes szignifikánsan nagyobb meredekségét mutatta $\left(\mathrm{F}_{1,316}=13,34 ; p<0,01\right)$. 


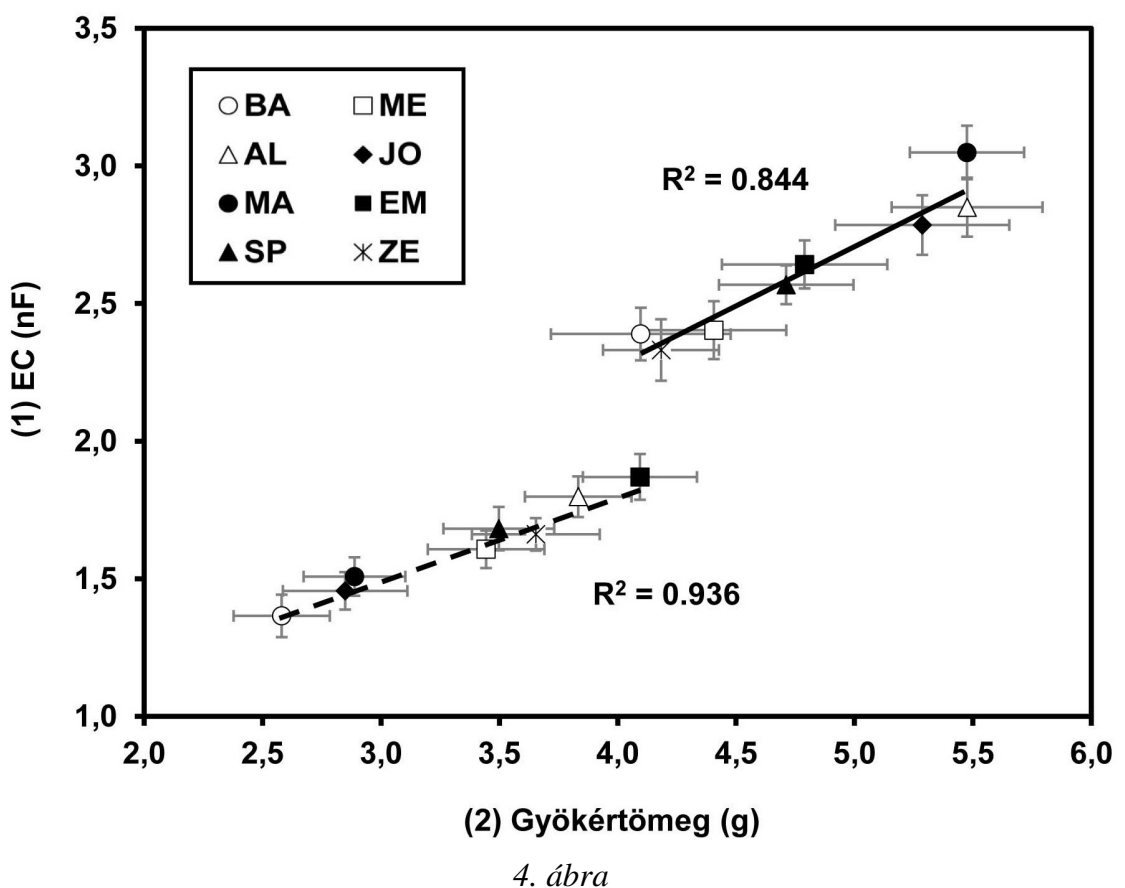

A gyökér elektromos kapacitása (EC) és tömege közötti összefüggés a kontroll és szárazságkezelt (folytonos, illetve szaggatott vonal) szójafajták esetén (n=160). Az ábrán csak az egyes csoportok (n=20) átlagát és szórását tüntettük fel. A fajták nevét lásd az 1. táblázatban.

\section{Az eredmények értékelése}

Eredményeink igazolják, hogy az EC-mérés alkalmas módszer a gyökérnövekedés fajtaspecifikus jellegének in situ monitorozására, és a környezeti tényezők okozta biomassza-változások becslésére. A gyökérméretben (EC-ben) lévő különbségek és időbeni változások megfelelnek a hagyományos eljárásokkal gyüjtött tapasztalatoknak. Bár a szója gyökértömege és -denzitása még a termésérés alatt is nöhet, a gyökérrendszer aktivitása - a növény vízigényével összhangban - a virágzáskor vagy a terméskötés kezdetén a legnagyobb, majd kisebb-nagyobb mértékben csökken (TORRION et al., 2012). A szuberin sejtfalakba épülése, a fajlagos vízfelvétel csökkenése és egyes gyökérrégiók elhalása az idősödö gyökérzet EC-jének csökkenéséhez vezet (DALTON et al., 1995; ELLIS et al., 2013; CSERESNYÉS et al., 2016). Korábbi vizsgálatok szerint az EC nemcsak a gyökérzet méretével arányos, hanem a vízfelvétel mértéke (permeabilitás) is befolyásolja, így a teljes gyökérrendszer aktivitását mutatja (CSERESNYÉS et al., 2013, 2014). A kontroll növényeknél az EC csökkenését csak a legkorábban virágzó két fajtánál tapasztaltuk, valószínüleg az általunk alkalmazott, viszonylag rövid tenyészidő miatt. A szárazságkezelés lerövidítette az egyes fenofázisokat, a stresszelt növények EC-jének csökkenését a kísérlet végéig hat fajta esetén is észleltük. 
A kísérlet végén mért EC különbségei jól jelezték az eltérő biomasszaprodukciókat. A vízhiány - fajtától függő mértékben - szignifikánsan csökkentette az EC-t, a gyökér- és hajtástömeget és a levélfelületet, valamint növelte a gyökér/hajtás arányt. Eredményeink összhangban állnak korábbi tapasztalatokkal, melyek szerint a toleráns szójafajták szárazságstressz mellett nagyobb gyökér/hajtás arányt és alacsonyabb talaj feletti biomassza-veszteséget mutatnak (KU et al., 2013; HOSSAIN et al., 2014). Az EC a szárazságtüréstől függően 28,8-50,5\%-kal csökkent a vízhiány hatására (2. táblázat). E változás minden fajtánál megbízhatóan (legfeljebb $\pm 5 \%$ ) eltéréssel jelezte mind a hajtástömeg, mind a levélfelület csökkenésének arányát. Ugyanakkor a gyökértömegben mutatkozó veszteség (12,647,3\%) lényegesen kisebb mértékü is lehet, mint amit az EC csökkenése jelez, különösen a szárazságtürő fajták (Emese és Zelma) esetén. Ennek oka, hogy a nagyobb szárazságtürés nagyobb gyökér/hajtás aránnyal párosul, ami csökkenti az egységnyi gyökértömegre eső hajtástömeget és levélfelületet, így a transzspiráción keresztül a fajlagos vízfelvételi rátát (SETIYONO et al., 2008; CSERESNYÉS et al., 2016). Mivel a gyökérméret és felvételi aktivitás az EC-ben együtt fejeződik ki, az azonos tömegü, de kisebb aktivitású gyökérzet EC-je (fajlagos EC) is kisebb lesz (CSERESNYÉS et al., 2014).

Mindezekre az elvégzett regresszióvizsgálatok is utalnak. A kontroll Bagera és Martina fajták nagyobb fajlagos EC-jét a kisebb gyökér/hajtás arányból eredő magasabb fajlagos vízfelvételi ráta okozza. A szárazság általánosan növeli a fajták gyökér/hajtás arányát, így csökkenti a fajlagos EC-t; a regressziós egyenes meredeksége $(0,317 \mathrm{nF} / \mathrm{g})$ ezért szignifikánsan alacsonyabb lesz, mint a kontroll növényeké $(0,437 \mathrm{nF} / \mathrm{g})$. Ehhez hozzájárul, hogy a szárazság fokozza a szuberin berakódását a gyökérszövetbe, csökkentve annak permittivitását és EC-jét (ELLIS et al., 2013; KU et al., 2013; CSERESNYÉS et al., 2016).

$\mathrm{Az}$ eredmények jól mutatják, hogy az EC-mérés alkalmazásakor az összehasonlító vizsgálatok során fokozott óvatossággal kell eljárni. Bár az EC és a gyökértömeg szoros korrelációt mutatott a kontroll és stresszelt növények esetén is, figyelembe kell venni, hogy az eltérö környezeti tényezők - még azonos növényfaj és közeg mellett is - befolyásolhatják az EC-gyökértömeg regresszió paramétereit, így a gyökértömeg-becslés pontosságát. Másfelől viszont éppen ez mutat rá az eljárás előnyére is: az EC egy aktuális - a teljes gyökérrendszerre vonatkozó felvételi aktivitást jelez, mely a puszta tömegénél, méreténél fontosabb, funkcionális mutatója a gyökérzetnek.

Mivel sok esetben az intenzívebb gyökérnövekedésü, nagyobb víz- és tápanyagfelvevő-képességü növényfajták terméshozama is nagyobb (KUMAGAI \& SAMESHIMA, 2014; WEI et al., 2015), a gyökérfejlődés és -aktivitás monitorozása gyakran elengedhetetlen a nagyobb hozamú változatok eredményes nemesítéséhez. A destruktív mintavételezésekkel vagy minirizotronnal végzett, idő- eszköz- és munkaigényes vizsgálatok mellett az egyszerü, in situ eljárások szerepe is fontos lehet. Az EC-mérés hátránya, hogy nem szolgáltat információt - a gyökérfunkciókra nézve fontos - morfológiai jellemzőkről (pl. gyökérdenzitás, mélységi megoszlás). Előnye viszont, a gyökéraktivitás jelzésén túl, hogy a vizsgálatot nem befolyásolja a szomszédos növények gyökereinek jelenléte 
(ČERMÁK et al., 2006). A gyors mérés a változások időbeli nyomon követésére is alkalmas, nem csak azok eredményéröl tájékoztat. Érdemes megemlíteni, hogy a vegetatív fázis egy rövid szakasza során igen intenzív gyökérnövekedést mutató Bagera, Johanna és Martina fajták bizonyultak a leginkább szárazságérzékenynek, és a kontroll növényekhez viszonyított biomassza-veszteségük az ezen időszakra eső szárazságperiódusban volt a legnagyobb. Mindez nem bizonyítja a hasonló gyökérnövekedési jelleg és a kisebb szárazságtürés közötti kapcsolatot, de a bemutatott módszer alkalmazása elősegítheti a hasonló összefüggések feltárását, ezáltal a nagyobb toleranciát mutató fajták kiválasztását.

Az EC mérése összehasonlító vizsgálatok során kalibrációk nélkül is alkalmazható, olcsó és gyors tesztmódszer. Segítségével - növényfajtól gyakorlatilag függetlenül - monitorozható a környezeti tényezők gyökérnövekedésre és -aktivitásra gyakorolt hatása is (CSERESNYÉS et al., 2014). Mivel a mérési eredmények összehasonlítása csak azonos talajtulajdonságok mellett lehetséges, az eljárás alkalmazhatósága szabadföldi körülmények között rendszerint korlátozott. Ennek ellenére számos tanulmány számol be a módszer sikeres használatáról szabadföldön végzett vizsgálatok során (PRESTON et al. 2004; SVAČINA et al. 2014; HEŘMANSKÁ et al. 2015).

A különböző környezeti hatásokkal szemben toleráns, vagy más kedvezö tulajdonságokkal bíró növényfajták vizsgálata és szelekciója agrár-gazdasági szempontból is kiemelkedő jelentöségü, szinte minden kultúrnövény esetén. Az ismertetett EC-mérés bevezetése, az általánosan használt destruktív, munka- és költségigényes eljárásokat kiegészítve vagy legalább részben helyettesítve, e kutatások során jelentős előnyökkel járhat.

\section{Összefoglalás}

Munkánk során tenyészedény-kísérlettel teszteltük az elektromos gyökérkapacitás (EC) mérés alkalmazhatóságát szójafajták gyökérnövekedésének és szárazságtürésének in situ vizsgálata céljából. A kontroll és a szárazságstressznek kitett növények EC-jét rendszeresen mértük, végül biomasszájukat destruktív eljárással meghatároztuk.

Az EC mérésével jól detektálható volt a fajták eltérő gyökérnövekedési dinamikája és biomassza-produkciója. Az EC - fajtától és kortól függő intenzitással - a virágzás kezdetéig folyamatosan emelkedett, majd közel állandóvá vált. A fajták EC-je és gyökértömege szoros korrelációt mutatott a kontroll $\left(\mathrm{R}^{2}=0,844\right)$ és a szárazságkezelt $\left(\mathrm{R}^{2}=0,936\right)$ növényeknél egyaránt. A vízhiány $28,8-50,5 \%$-kal csökkentette az egyes fajták EC-jét, ami összhangban állt azok hajtástömegeinek 25,5-49,1\%-os, és levélfelületeinek (transzspirációjának) 23,6-51,5\%-os csökkenésével, ugyanakkor több fajtánál lényegesen meghaladta a gyökértömegben mutatkozó veszteséget $(12,6-47,3 \%)$. Ennek oka, hogy a szárazság hatására nőtt a gyökér/hajtás arány (3,9-21,9\%-kal), ezért csökkent az egységnyi gyökértömegre eső (fajlagos) vízfelvétel, így a fajlagos EC is. Mindezt alátámasztotta az ECgyökértömeg regressziós egyenes meredekségének csökkenése (kontroll: 0,437 nF/g gyökér; szárazságkezelt: és 0,317 nF/g gyökér). Megállapítható, hogy az EC a 
teljes gyökérrendszer felvételi aktivitását jelzi, így - a gyökértömeggel szemben funkcionális mutatója is a gyökérzet aktuális állapotának.

Eredményeink alapján az EC mérése hatékony módszer a gyökérnövekedési dinamika fajtaspecifikus különbségeinek vizsgálatára, valamint a környezeti hatások okozta biomassza-veszteség becslésére. Az in situ eljárás a hagyományos technikák mellett az agrártudományi kutatások számos területén (pl. fajtaszelekció, stressztürés-vizsgálatok) haszonnal járhat.

Kulcsszavak: biomassza-csökkenés, gyökéraktivitás, elektromos kapacitás, in situ gyökérvizsgálatok, szárazságstressz

Munkánkat a Nemzeti Kutatási, Fejlesztési és Innovációs Hivatal (K-115714), az Ökológiai és Mezőgazdasági Kutatóintézet, valamint a Bolyai János Kutatási Ösztöndíj támogatásával végeztük. A vetőmagot a Kaposvári Egyetem Takarmánytermesztési Kutatóintézete és a SUMI AGRO Hungary Kft. biztosította.

\section{Irodalom}

Cao, Y., Repo, T., Silvennoinen, R., Lehto, T. \& Pelkonen, P., 2010. An appraisal of the electrical resistance method for assessing root surface area. Journal of Experimental Botany. 61. 2491-2497.

ČERMÁK, J., UlRICH, R., STANĚK, Z., Koller, J., AUBreCht, L., 2006: Electrical measurement of tree root absorbing surfaces by the earth impedance method: 2 . Verification based on allometric relationships and root severing experiments. Tree Physiology. 26. 1113-1121.

CHLOUPEK, O., 1972. The relationship between electric capacitance and some other parameters of plant roots. Biologia Plantarum. 14. 227-230.

ChloupeK, O., Dostál, V., StŘeda, T., Psota, V. \& DvoŘÁčKová, O., 2010. Drought tolerance of barley varieties in relation to their root system size. Plant Breeding. 129. 630-636.

Cseresnyés, I., TAKÁCs, T., VéGH, R. K., Anton, A., \& RAJKai, K., 2013. Electrical impedance and capacitance method: a new approach for detection of functional aspects of arbuscular mycorrhizal colonization in maize. European Journal of Soil Biology. 54. 25-31.

Cseresnyés, I., TAKÁCS, T., FÜZY, A. \& RAJKaI, K., 2014. Simultaneous monitoring of electrical capacitance and water uptake activity of plant root system. International Agrophysics. 28. 537-541.

CSERESNYÉS, I., RAJKAI, K., \& TAKÁCS, T., 2016. Indirect monitoring of root activity in soybean cultivars under contrasting moisture regimes by measuring electrical capacitance. Acta Physiologiae Plantarum. 38. No. 121, 12 pp.

DALTON, F. N., 1995. In-situ root extent measurements by electrical capacitance methods. Plant and Soil. 173. 157-165.

Ellis, T., MurRaY, W. \& KaVAlieris, L., 2013. Electrical capacitance of bean (Vicia faba) root systems was related to tissue density - a test for the Dalton Model. Plant and Soil. 366. 575-584. 
Heřmanská, A., StředA, T. \& CHLOUPEK, O., 2015. Improved wheat grain yield by a new method of root selection. Agronomy for Sustainable Development. 35. 195-202.

Hossain, M. M., LIU, X., QI, X., LAM, H-M., ZHANG, J., 2014. Differences between soybean genotypes in physiological response to sequential soil drying and rewetting. The Crop Journal. 2. 366-380.

Ku, Y-S., AU-Yeung, W-K., Yung, Y-L., LI, M-W., Wen, C-Q., LiU, X., LAM, HM., 2013. Drought stress and tolerance in soybean. In: BOARD, J. E. (ed.): A comprehensive survey of international soybean research - Genetics, physiology, agronomy and nitrogen relationships. InTech, Rijeka, pp. 209-237.

Kumagai, E., SAmeshima, R., 2014. Genotypic differences in soybean yield responses to increasing temperature in a cool climate are related to maturity group. Agricultural and Forest Meteorology. 198-199. 265-272.

OZIER-LAFONTAINE, H., BAJAZET, T., 2005. Analysis of root growth by impedance spectroscopy (EIS). Plant and Soil. 277. 299-313.

Pitre, F. E., Brereton, N. J. B., Audoire, S., Richter, G. M., Shield, I., KarP, A., 2010. Estimating root biomass in Salix viminalis $\times$ Salix schwerinii cultivar "Olof" using the electrical capacitance method. Plant Biosystems. 144. 479483.

Preston, G. M., McBride, R. A., Bryan, J., CANDido, M., 2004. Estimating root mass in young hybrid poplar trees using the electrical capacitance method. Agroforestry Systems. 60. 305-309.

RAJKAI, K., VÉGH, R. K., NACSA, T., 2005. Electrical capacitance of roots in relation to plant electrodes, measuring frequency and root media. Acta Agronomica Hungarica. 53. 197-210.

Setiyono, T. D., Weiss, A., Specht J. E., CAssman, K. G., Dobermann, A., 2008. Leaf area index simulation in soybean grown under near-optimal conditions. Field Crops Research. 108. 82-92.

Středa, T., Dostál, V., Horáková, V., ChloupeK, O., 2012. Effective use of water by wheat varieties with different root system size in rain-fed experiments in Central Europe. Agricultural Water Management. 104. 203-209.

SvaČINA, P., StředA, T., CHLOUPEK, O., 2014. Uncommon selection by root system size increases barley yield. Agronomy for Sustainable Development. 34. 545-551.

Torrion, J. A., Setiyono, T. D., Cassman, K. G., Ferguson, R. B., Irmak, S., SPECHT, J. E., 2012. Soybean root development relative to vegetative and reproductive phenology: Agronomy Journal. 104. 1702-1709.

Turman, P. C., Wiebold, W. J., Wrather, J. A., Tracy, P. W., 1995. Cultivar and planting date effects on soybean root growth. Plant and Soil. 176. 235-241.

Wei, Z., Paredes, P., LiU, Y., ChI, W. W., Pereira, L. S., 2015. Modelling transpiration, soil evaporation and yield prediction of soybean in North China Plain. Agricultural Water Management. 147. 43-53. 


\title{
In situ investigation of root growth and drought tolerance of soybean cultivars by measuring electrical capacitance
}

\author{
I. CSERESNYÉS, K. RAJKAI, T. TAKÁCS
}

Institute for Soil Sciences and Agricultural Chemistry, Centre for Agricultural Research, Hungarian Academy of Sciences, Budapest (Hungary)

\section{Summary}

The study was aimed to test the applicability of root electrical capacitance (EC) measurement for the in situ investigation of the root growth and drought tolerance of soybean cultivars. Control and drought-stressed plants were cultivated in pots with repeated measurements of their root EC, followed terminally by destructive harvest.

Root EC measurements clearly reflected the variability in the root growth characteristics and biomass production of different cultivars. An increase in EC, the intensity of which varied with cultivar and age, was observed until the beginning of flowering, after which it became nearly constant. The final EC was closely correlated with root mass for both control $\left(\mathrm{R}^{2}=0.844\right)$ and stressed plants $\left(\mathrm{R}^{2}=0.936\right)$. Drought reduced the EC of the cultivars by $28.8-50.5 \%$, which was consistent with the corresponding changes in shoot mass (25.5-49.1\%) and leaf area (23.6-51.5\%), but considerably exceeded the loss of root mass (12.6-47.3\%) in some cultivars. This could be attributed to the fact that drought increased the root/shoot ratio (by 3.9-21.9\%), leading to a decrease in water uptake and thus in EC per unit of root mass. This was confirmed by the significant decrease in the slope of the EC-root mass regression line from 0.437 to $0.317 \mathrm{nF} / \mathrm{g}$ root in control and drought-stressed plants, respectively. As EC reflects the uptake activity of the whole root system, it was a better indicator of the actual root status than root mass.

The results suggested that EC measurement was an adequate method for detecting cultivar-specific differences in root growth and for estimating the biomass loss caused by drought. As a supplementation of conventional methods, the new in situ technique could be useful in various fields of agriculture, including cultivar selection and stress tolerance studies.

Table 1. Characteristics of the soybean cultivars tested. (1) Cultivar name. (2) Cultivar symbol. (3) Maturity group. (4) Flowering (day). ${ }^{\text {(a) }}$ Beginning of flowering in control (first value) and drought-stressed plants (second value).

Table 2. Percentage change in the properties of soybean cultivars in response to drought stress, with significance levels obtained using the unpaired $t$-test. ***, **, * $p<0.001,0.01$ and 0.05 , respectively; NS, non-significant. (1) Cultivar symbol. (2) Electrical capacitance. (3) Root dry mass. (4) Shoot dry mass. (5) Root/shoot ratio. (6) Leaf area. ${ }^{\text {(a) }}$ See Table 1 for cultivar symbols.

Figure 1. Mean changes in root electrical capacitance (EC) for (A) control and (B) drought-stressed soybean cultivars. Vertical bars show standard deviations. 
Small letters indicate groups distinguished by the Tukey-Kramer test $(p<0.05)$. See Table 1 for cultivar symbols. (1) Electrical capacitance. (2) Plant age in days.

Figure 2. Percentage ratio of the root electrical capacitance (EC) of droughtstressed to non-stressed soybean cultivars over time. (1) Electrical capacitance ratio. (2) Plant age in days.

Figure 3. (A) Root and (B) shoot dry mass, (C) root/shoot ratio and (D) leaf area of control and drought-stressed soybean cultivars (grey and white columns, respectively). Vertical bars show standard deviations. See Table 1 for cultivar symbols. (1) Root dry mass. (2) Shoot dry mass. (3) Root/shoot ratio. (4) Leaf area.

Figure 4. Correlation between root electrical capacitance (EC) and root dry mass in control and drought-stressed soybean cultivars (solid and dashed lines, respectively; $\mathrm{n}=160$ ). Only the mean and standard deviation of each plant group $(\mathrm{n}=20)$ are plotted. See Table 1 for cultivar symbols. (1) Electrical capacitance. (2) Root dry mass.

Keywords: biomass loss, root activity, electrical capacitance, in situ root investigations, drought stress 